\title{
A EXPERIÊNCIA DA FORMAÇÃO DE PROFESSORES DE ENSINO RELIGIOSO NA UNIVERSIDADE ESTADUAL DO NORTE DO PARANÁ
}

\author{
The experience of teacher training of Religious Education in the State University of \\ North of Paraná
}

\author{
Alfredo Moreira da Silva ${ }^{1}$ \\ Fábio Antônio Gabriel ${ }^{2}$
}

\begin{abstract}
RESUMO: Neste artigo, pretende-se expor a experiência formativa de professores de ensino religioso no contexto da primeira turma do Programa Nacional de Formação de Professores da Educação Básica (PARFOR) na Universidade Estadual do Norte do Paraná (UENP). A revisão de literatura na área de formação de professores de ensino religioso aponta no sentido de uma preocupação muito acentuada com a formação continuada desses docentes e pouca preocupação com a formação inicial em licenciaturas de Ciências da Religião. Defende-se, assim, a importância de que os docentes de ensino religioso se formem em cursos de licenciatura específica. A metodologia da pesquisa norteou-se pela aplicação de questionário para os formados nessa primeira turma na UENP. Os resultados evidenciam um impacto não apenas epistemológico na concepção do ensino religioso após a formação em Ciências da Religião, como também uma mudança de visão didática sobre o que constitui a identidade de ser professor de ensino religioso.
\end{abstract}

PALAVRAS-CHAVE: Ciências da religião. Professores. Ensino religioso. Experiência formativa.

\begin{abstract}
In this paper, we intend to present the training experience of teachers of Religious Education within the context of the first group of the National Program of Teacher Training of Basic Education (known as PARFOR) at the Universidade Estadual do Norte do Paraná (UENP) - State University of the North of Paraná, Brazil. The literature review in the area of teacher training in Religious Education points to a very strong concern with the continuing education of these teachers and little concern for initial training in Science of Religion teaching degrees. It is therefore advocated that teachers of Religious Education be trained in specific undergraduate teaching courses. The methodology of the research was guided by the application of a questionnaire for those who graduated in this first group at UENP. The results show not only an epistemological impact in the conception of Religious Education following the degree in Science of Religion, but also a change in the didactic vision of what constitutes the identity of being a teacher of Religious Education.
\end{abstract}

KEYWORDS: Science of religion. Teachers. Religious Education. Formative experience.

\footnotetext{
${ }^{1}$ Doutor em Ciências da Religião pela PUC-SP, Professor Adjunto do Centro de Ciências Humanas e Educação da Universidade Estadual do Norte do Paraná - Campus Jacarezinho. E-mail: alfredo@uenp.edu.br

2 Doutorando em Educação na Universidade Estadual de Ponta Grossa. Bolsista de doutorado CAPES/FUNDAÇÃO ARAUCÁRIA. O presente trabalho foi realizado com apoio da Coordenação de Aperfeiçoamento de Pessoal de Nível Superior - Brasil (CAPES). E-mail: fabioantoniogabriel@ gmail.com
} 


\section{Introdução:}

Neste artigo, pretende-se expor a experiência na formação de professores de Ensino Religioso no contexto da primeira turma do Programa Nacional de Formação de Professores da Educação Básica (PARFOR) na Universidade Estadual do Norte do Paraná (UENP), vale ressaltar que o referido curso foi proposto e tramitado nas instâncias da Universidade em 2015 e iniciado em março de 2016 sendo o primeiro e único curso de Ciência das Religiões e Ensino Religioso oferecido na Modalidade PARFOR no Paraná, deste modo, torna-se necessário e justificável um estudo que destaque as contribuições desse curso para o campo de formação de professores, suas características e resultados alcançados .

A revisão de literatura na área de formação de professores de ensino religioso aponta no sentido de uma preocupação muito acentuada com a formação continuada desses docentes e pouca preocupação com a formação inicial em licenciaturas de Ciências da Religião, JUNQUEIRA ( 2010), aponta que no período 1995 a 2010 foram pesquisados vários cursos de formação de professores de Ensino Religioso por todo o país de forma que:

\begin{abstract}
Nesse cenário foram pesquisados propostas de 106 cursos nas modalidades do Ensino Médio, Graduação, Extensão e Especialização, sendo que 90 são da modalidade presencial e 16 na modalidade da Educação a Distância (EAD) e/ou Semi-Presencial. O material pesquisado foi referente a um curso de Ensino Médio (modalidade EAD), 21 cursos de graduação (sete bacharelados e 14 licenciaturas, sendo que destes dois na modalidade EAD), 14 cursos de extensão (sendo cinco na modalidade EAD) e 70 cursos de especialização (sendo oito na modalidade EAD). ( JUNQUEIRA, 2010, p. 72-73)
\end{abstract}

A nosso ver, os números citados acima, refletem a predominância dos cursos de formação continuada, notadamente os cursos de especialização e extensão, em detrimento de cursos de graduação voltados especificamente para atendimento da necessidade do profissional de Ensino Religioso com perfil mais adequado.

Ao longo do artigo pretendemos demonstrar a importância de que os docentes de Ensino Religioso se formem num curso de licenciatura específica, para tanto, utilizamos quanto aos procedimentos metodológicos, a pesquisa bibliográfica tendo como fontes a Legislação ordinária sobre o Ensino Religioso e o PPC - Projeto Pedagógico do Curso de Ciências da Religião e Ensino Religioso da UENP e a pesquisa "Participante" sendo que esta última, 
segundo GERHARDT e SILVEIRA ( 2009, p.40) "caracteriza-se pelo envolvimento e identificação do pesquisador com as pessoas investigadas." Quanto a abordagem, lançamos mão da análise "Qualitativa” pois, conforme nos ensina DEMO (1995, p. 244):

Avaliação qualitativa é participativa, porque fazemos qualidade coincidir com participação, em seu núcleo mais central. No fundo, é auto-avaliação, cabendo-lhe a perspectiva metodológica delineada na pesquisa participante.

Não é possível fazer avaliação qualitativa a distância, ou de modo intermitente, esporádico, por encomenda, por terceiros. Convivência é o mínimo que se exige.

Buscou-se através da aplicação de questionário para os formados nessa primeira turma na UENP que cada formando buscasse fazer uma auto análise do impacto do curso em seu cotidiano escolar, após a tabulação dos dados, buscou-se uma análise qualitativa das respostas com base na comparação do desempenho de cada participante ao longo do curso e a evolução de cada um rumo aos objetivos pretendidos no curso.

Visando uma explanação que dê conta dos motivos que originaram o curso de Ciências da Religião e Ensino Religioso da UENP, suas características, especificidades e resultados, dividiremos nosso artigo em quatro tópicos: Histórico da criação do Curso , O ensino religioso como Ciência da religião: pressupostos epistemológicos, Formação de Professores de Ensino Religioso e Resultados Obtidos.

Não é nosso intuito fazermos uma análise pormenorizada e exaustiva dos aspectos epistemológicos ou pedagógicos do curso, apenas um relato de experiências e o impacto deste na formação acadêmica e na visão de mundo de seus egressos.

\section{Contexto Histórico da Criação do Curso de Ciências da Religião na UENP}

O curso de Ciências da Religião da UENP surgiu como um apêndice do curso de História, este por sua vez, foi criado em 1960 na Faculdade Estadual de Filosofia, Ciências e Letras de Jacarezinho (FAFIJA), transformada em 2010 no Centro de Ciências Humanas e Educação uma das unidades que integram a Universidade Estadual do Norte do Paraná (UENP).

No decorrer dos seus cinquenta e nove anos de existência, o curso de História da UENP formou mais de cinco mil profissionais, e se destacou na região do Norte Pioneiro exatamente por se consolidar como a licenciatura que formou a grande maioria dos professores dessa área 
atuantes em escolas públicas e privadas no Norte Pioneiro do Paraná e Sul de São Paulo , além de ofertar cursos de pós-graduação que possibilitam a estes profissionais a formação continuada. Tornou-se assim um curso de referência dentre os ofertados pelas universidades do interior do Paraná e estendeu sua influência para regiões mais distantes, atraindo alunos de várias cidades do Estado do Paraná e do Estado de São Paulo.

Em decorrência dessa predisposição no curso de História, de serem empreendidos esforços para a formação de professores, foram criados diversos Grupos de Pesquisa, sendo o primeiro deles o Núcleo de Pesquisa em História das Religiões - NPHR em 2005, tendo produzido bons frutos e sendo integrado, 14 anos depois de seu início por professores doutores que foram seus primeiros bolsistas de Iniciação Científica enquanto ainda cursavam sua graduação.

É diante desse quadro de formação de professores-pesquisadores na área de História das Religiões que surgiu a iniciativa de se desenvolver a proposta de curso de segunda licenciatura em Ciências da Religião.

A formação específica de professores graduados em Ciências da Religião e Habilitados para o Ensino Religioso, traria consequências expressivas para o contexto educacional e científico de toda esta região, com sensível melhora do setor educacional, em médio e longo prazos.

Outro dado importante é que desde 2008, a disciplina de História das Religiões foi incorporada à grade curricular do curso o que contribui, juntamente com o NPHR para a continuidade de estudos e pesquisas na área.

Entendemos que a religião e as religiosidades assumem um papel de destaque na sociedade brasileira, cada vez mais, observamos o crescimento de religiões que antes ocupavam um papel marginal em termos de influência sócio-política e hoje protagonizam um papel importante em diversos setores, inclusive no Congresso Nacional e na grande mídia. Ao mesmo tempo, desenvolveu-se movimentos religiosos ligados à New Age, Santo Daime e religiões de matriz africana , porém, a multiplicidade de religiões e religiosidade que permeiam a sociedade brasileira contemporânea não tem garantido a tolerância religiosa, pelo contrário, quase que cotidianamente nos deparamos com episódios lamentáveis que vão desde quebradeiras de imagens sacras até a invasão de templos e espancamento de líderes religiosos. Neste contexto, 


\section{relegens thrésketa}

em 2015 através do PARFOR-MEC ${ }^{3}$ entendeu-se necessária a elaboração de um projeto de curso de formação de professores em segunda licenciatura em Ensino Religioso.

Para a viabilização do projeto foi levantado o perfil formativo dos docentes das cidades mais próximas ao Campus Jacarezinho da UENP, aonde seria sediado o curso e observou-se um número razoável de profissionais que lecionavam a disciplina de ensino religioso sem ter a formação específica, desta forma, foram realizadas reuniões nas escolas para esclarecimento dos objetivos do PARFOR e das características do curso de formação de professores na área de Ensino Religioso, nestas reuniões observamos uma grande curiosidade por parte dos docentes, vale dizer, de todas as áreas, sobre o curso e interesse em realizá-lo tão somente para ampliação de seus conhecimentos, infelizmente, este público não pode ser contemplado segundo as regras do PARFOR . Se inscreveram para a matrícula pouco mais de 60 profissionais porém somente 35 estavam elegíveis segundo as regras do edital pois priorizava-se aqueles que já lecionavam a disciplina.

Vale ressaltar as dificuldades enfrentadas pelo atraso no início das aulas por conta do contingenciamento de verbas pelo Governo Federal, foram mais de seis meses de espera para a liberação das bolsas que seriam atribuídas aos docentes do curso , tal fato contribuiu para a desistência de grande parte do público selecionado inicialmente, apenas 18 confirmaram a matrícula e iniciaram o curso, destes, apenas 8 concluíram, dentre os possíveis motivos dessa grande evasão estão as greves na Rede Estadual de Ensino abrangendo desde a educação básica até as Universidades Estaduais e Federais, as greves duraram em alguns casos até 6 meses causando diversos transtornos na esfera pedagógica. O difícil contexto político e econômico daquele momento também contribuiu para a desistência de muitos acadêmicos pois, ao longo do processo de impeachment da Presidente Dilma (durou aproximadamente 8 meses de 02/12/2015 a 31/08/2016), houve uma grande incerteza quanto à sobrevivência de muitos programas educacionais, dentre eles o próprio PARFOR.

O perfil imaginado para o curso a ser ofertado indicava que fosse pautado em estudos e pesquisas que abordassem o papel sócio-cultural das religiões e religiosidades por um viés baseado em pressupostos epistemológicos norteados pela Ciência das Religiões , superando o

\footnotetext{
${ }^{3}$ O Plano Nacional de Formação de Professores da Educação Básica (PARFOR), foi promovido pelo MEC Ministério da Educação, em parceria com as Universidades Públicas visando a oferta de cursos superiores aos professores da rede pública de ensino que lecionavam em área diferente de sua formação.
} 
ensino proselitista e priorizando-se uma reflexão que permitisse a compreensão dos fenômenos religiosos e as diferentes visões de mundo que ele proporciona de maneira a superar preconceitos e discriminações.

\section{O ensino religioso como ciência da religião}

É sabido que durante o surgimento e consolidação deste campo teórico, em determinados momentos, os termos História das Religiões e Ciência das Religiões se fundiam, no entanto, a complexidade dos fenômenos religiosos levou alguns intelectuais a defenderem, já no final do século XIX, a constituição de uma disciplina com estatuto epistemológico autônomo em relação à História das Religiões, assim, surge em 1870 com Max Müller, uma proposta de constituição da Ciência da Religião como uma disciplina comparativa o que, de fato, pouco contribuiu para a constituição de um campo de investigação mais amplo e de um estatuto epistemológico que leve em conta os objetos pesquisados. É com Joachim Wach (1898-1955) que a Ciência das Religiões para a ter o caráter da interdisciplinariedade, além do empirismo histórico, comparativista e sistematizado.

O termo religião, segundo GRESCHAT (2005 ) está enraizado no imaginário europeu como algo ligado ao cristianismo, da mesma forma que a ciência da religião é vista pelos leigos como algo ligado ou derivado da teologia , tais práticas acabaram por fazer o ministério da educação alemão instituir como ensino religioso o ensino do catolicismo ou protestantismo , da união entre teólogos católicos e protestantes surgiu a faculdade intitulada de Ciência da Religião .

A complexidade do termo religião sucumbia inicialmente, ao etnocentrismo europeu, e às abstrações de que era possível, por exemplo, se falar em religião cristã "enquadrando" todas as vertentes do cristianismo como genericamente iguais. Alguns pensadores europeus, tentaram identificar a essência das religiões numa tentativa de uni-las, por outro lado, o que não seria essencial, as separaria. As peculiaridades de cada religião, portanto, eram negligenciadas num primeiro momento.

As definições de religião foram tomando diferentes formatos ao longo do tempo, dizendo respeito a seres espirituais para uns, a promessa de redenção para outros, uma neurose coletiva, ou ainda o ópio do povo, de qualquer forma, a maioria das definições surgidas levava em conta as religiões cristãs. 


\section{relegens thrésketa}

A ciência da religião, portanto, surge da dificuldade em simplesmente conceituar o que seja religião e não o oposto, porém, o objeto desta ciência permanece não obstante à dificuldade em conceituá-lo.

Um cientista da religião, quando exerce sua profissão, deve colocar um parêntese em sua fé pessoal, uma vez que, se ela sobressaísse, poderia distorcer o objeto pesquisado. Tal distorção aparece quando o pesquisador - em vez de olhar e ouvir com a mente aberta - parte para avaliações espontâneas e descontroladas, feita com a cabeça repleta de comparações. A recepção de algo desconhecido gasta toda a nossa energia. Enquanto passamos por esse processo, deveríamos suspender nossos julgamentos.

Em muitas religiões há esferas ocultas. Fica em aberto a questão de como cientistas da religião devem obter informações sobre uma religião quando seus adeptos impossibilitam o acesso a elas.

Quando um fiel abre voluntariamente suas portas, não precisamos arrombá-las. Até que isso aconteça, temos de esperar, pois ainda não chegou o momento certo. Em primeiro lugar, os cientistas da religião devem entender os fiéis. Temos de lhes mostrar nossa paciência, uma vez que não é fácil, para eles, destravar suas portas para nós. É possível que pensem e discutam por um bom tempo ou, até mesmo, que prefiram aguardar um sinal de seus ancestrais ou deuses.

Para vivenciarmos o momento acima especificado podemos posicionar-nos no centro da vida religiosa e observar o que ocorre ao nosso redor ou entregar-nos ao fluxo da vida religiosa e dela participar ativamente.

A observação é o método científico por excelência, observa-se o que acontece.

Os cientistas da religião aprenderam a ver os fiéis como fontes importantes. De acordo com sua formação acadêmica, utilizam tais fontes do mesmo modo que fariam com outras. Explora-se uma fonte o mais possível. Estudam-se profundamente as afirmações dos fiéis advindas de perguntas metodologicamente construídas e controladas. As respostas não somente dizem de onde vem o saber religioso dos fiéis, o que eles mesmos, seus pais e seus filhos pensam sobre aquilo que sabem; elas também apontam para o que não é dito aos pesquisadores e para os motivos desse silêncio.

Pode-se perguntar ou observar algo, mas há aspectos da realidade que o pesquisador compreende apenas se empreendê-los. 
Temos de "obrigatoriamente" passar por algumas experiências para entender uma religião alheia melhor.

No Brasil, Usarski ( 2007), talvez seja o maior pesquisador da escola alemã da Ciência das Religiões e o mesmo defende a Ciência das Religiões como disciplina empírica, historicizante, comparativa, interpretativa, sistemática e diversificada quanto ao objeto e interdisciplinar, um verdadeiro ponto de encontro entre contribuições teóricas oriundas de outras disciplinas sem, contudo, deixar de ser uma disciplina autônoma com campo epistemologicamente definido. colocou que:

Além do exposto, o FONAPER ${ }^{4}$ (Fórum Nacional Permanente do Ensino Religioso),

As diferentes Ciências Humanas, integradas às Ciências da Religião, contribuem na definição dos conteúdos específicos, considerando que a interlocução entre as mesmas é fundamental para a construção e a articulação da disciplinaridade e da interdisciplinaridade. O ER tem necessidade de observar tais aspectos, pois objetiva compreender o fenômeno religioso na diversidade de situações da existência humana.

As Ciências da Religião, ao se constituírem como uma das bases epistemológicas para o ER, contribuem para a compreensão do humano enquanto ser em/de busca, aberto à transcendência e histórico-culturalmente situado dentro de referências religiosas, influenciadas por elas de múltiplas maneiras e, muitas vezes, agindo a partir delas. Nesse sentido, o estudo do fenômeno religioso num Estado laico, a partir de pressupostos científicos, visa à formação de cidadãos críticos e responsáveis, capazes de discernir a dinâmica dos fenômenos religiosos, que perpassam a vida em âmbito pessoal, local e mundial. Por outro lado, o pressuposto pedagógico sustenta a proposta do ER na escola. As diferentes crenças, grupos e tradições religiosas e/ou a ausência delas são aspectos da realidade que não devem ser meramente classificados como negativos ou positivos, mas sim como dados antropológicos e socioculturais capazes de fundamentar e interpretar as ações humanas. Nessa perspectiva, a formação específica em nível superior, em cursos de Graduação em Ciências da Religião-Licenciatura em Ensino Religioso, integra os pressupostos das áreas: Ciências da Religião e Educação, a fim de que o licenciado possa trabalhar pedagogicamente numa perspectiva inter-religiosa, enfocando o fenômeno religioso como construção sóciohistórico-cultural.

Com base nas discussões teóricas já explicitadas, fez-se necessário o oferecimento de um curso e Ciências da Religião que buscasse atender aos pressupostos epistemológicos próprios do estudo das religiões e ao mesmo tempo, exigências atuais da educação pública tais como: o ensino de LIBRAS, inserido no currículo como disciplina e outros temas como a

\footnotetext{
${ }^{4}$ Disponível em http://www.fonaper.com.br/documentos.php
} 
Educação Ambiental e a Cultura Afro-brasileira e Africana na forma de conteúdos da disciplina Geografia da Religião e Geografia e ainda, da disciplina de Culturas Religiosas no Brasil.

Partiu-se do pressuposto epistemológico de se considerar o ensino religioso como ciência da religião, rechaçando toda e qualquer espécie de proselitismo. Um dos autores desta pesquisa lecionou a disciplina Antropologia e Religiões e foram visíveis as contribuições dos trabalhos apresentados em grupo, em conhecimentos enriquecedores que a antropologia e outras disciplinas como a filosofia e a sociologia (além de outras disciplinas do curso) ofereceram para se pensar o fenômeno religioso como um fator humano que interfere nas relações cotidianas, e cujo impacto reflete-se em toda a sociedade de acordo com a religião professada.

\begin{abstract}
Nesse sentido, o estudo do fenômeno religioso num Estado laico, a partir de pressupostos científicos, visa a formação de cidadãos críticos e responsáveis, capazes de discernir a dinâmica dos fenômenos religiosos, que perpassam a vida em âmbito pessoal, local e mundial. É o pressuposto pedagógico que sustenta a proposta do Ensino Religioso na escola, com as diferentes crenças, grupos e tradições religiosas e/ou na ausência deles. Esses são aspectos da realidade que não devem ser meramente classificados como negativos ou positivos, mas sim como dados antropológicos e socioculturais capazes de fundamentar e interpretar as ações humanas. (JUNQUEIRA, 2010, p.71)
\end{abstract}

O perfil dos acadêmicos contribuiu muito para o bom andamento e êxito nas atividades, isso porque já eram professores e muitos já atuavam como professores de ensino religioso. Nos dizeres de Dissenha e Junqueira (2015, p.32):

O Ensino Religioso como área de conhecimento está fundamentado numa releitura religiosa do cotidiano, respaldado no estudo do ser humano em desenvolvimento, que sustenta a estrutura social das diferentes comunidades das quais participa, inclusive no processo de construção de um cidadão que compreende a pluralidade da sociedade. Ressalva-se a clareza de que essa área do conhecimento exige ainda uma reflexão pedagógica profunda em sua estruturação, o que demanda o estabelecimento de fundamentos para sua estruturação, no mapeamento curricular nacional. (DISSENHA; JUNQUEIRA, 2015, p.32)

Percebeu-se, ao longo do processo formativo, um amadurecimento dos acadêmicos no entendimento do ensino religioso como Ciência da Religião. Muitos relataram como alguns de seus colegas dedicam-se ao ensino religioso com muita disposição, mas por não terem adequada formação epistemológica sobre o ensino religioso dedicam-se a ministrar aulas da convicção 
religiosa que praticam. Infelizmente, algumas instituições religiosas tem buscado pressionar o próprio executivo e legislativo a formatar o ensino religioso em perspectiva extremamente confessional.

O objeto do Ensino Religioso é o fenômeno religioso em suas diversas manifestações que causam um impacto no cotidiano das pessoas. Nas palavras de Dissenha; Junqueira, 2015, p.48:

A religião pode influenciar e definir as relações humanas, emprestando sentido, quando valida uma gama de informações, aferindo veracidade a elas. Além disso, serve de modelo enquanto baliza ações e responde questões cruciais para a vida, como aquelas ligadas à identidade (quem sou? Porque estou aqui?) e destino (de onde vim? Para onde vou?), além daqueles questionamentos quanto às ameaças de sofrimento, ignorância e injustiça. Instintivamente, há uma tendência à busca de comportamentos religiosos, independente da cultura a que pertença, por ser instrumento para o conhecimento e compreensão do mundo, de si e de ações e fenômenos incontroláveis, inexplicáveis e desconhecidos. (DISSENHA; JUNQUEIRA, 2015, p.48)

Entendemos que um dos desafios do ensino religioso no ambiente escolar é que ele possa contribuir para atenuar os preconceitos em relação à religião alheia. $\mathrm{O}$ ser humano tem uma tendência, diante do desconhecido e do diferente, de desvalorizar e entender que o que é diferente do seu é inferior, assim, DOMINGOS (2009, p.55-56) nos coloca que:

No mundo de hoje, a tolerância e a laicidade não podem encontrar bases mais sólidas que o conhecimento e o respeito do outro, pois é o enclausuramento e a ignorância que alimentam os preconceitos e os comunitarismos. Reforçar o conhecimento das religiões, melhorar o ensino do fato religioso (...), confortará o espírito de tolerância nos nossos concidadãos, dando-lhes meios de melhor respeitar uns aos outros.

Neste sentido, é importante o ensino religioso para demonstrar que existem diversas matrizes religiosas e que, antropologicamente, essas matrizes contribuem para se pensar na importância de cada religião na constituição religiosa de um determinado povo.

Importante também, na formação do futuro professor de Filosofia, que ele compreenda a relevância da autocrítica, analisando se não está sendo preconceituoso com determinada crença religiosa, porque, se o professor de Ensino Religioso for preconceituoso, tenderá a transmitir esse preconceito para seus alunos.

Por todas as razões expostas, defendemos O Ensino Religioso, enquanto parte integrante da formação básica do cidadão e área do conhecimento das diretrizes curriculares 
(Resolução CNE/CEB nº 4, de 13 de julho de 2010), responsável por assegurar o respeito a diversidade cultural religiosa na escola.

Nesta perspectiva, o Ensino Religioso objetiva proporcionar o conhecimento dos elementos básicos que compõem o fenômeno religioso, a fim de possibilitar esclarecimentos sobre o direito à diferença, valorizando o pluralismo e a diversidade cultural presente na sociedade, para que as culturas sejam conhecidas em mesmo grau e valor, promovendo e exercitando a liberdade de concepções e a construção da autonomia e da cidadania, prerrogativas de um estado laico e democrático.

\section{Formação de professores de Ensino Religioso}

Junqueira (2010, p.66) destaca a importância histórica do FONAPER na constituição da disciplina Ensino Religioso como um campo do saber sobre ciências da religião e no surgimento de cursos de licenciatura em Ciências da Religião. Como em outras áreas do conhecimento, é significativa a diferença que se estabelece entre professor é formado em área específica ao conteúdo em que irá ministrar aulas e o professor que oferece aulas apenas porque é praticante de uma determinada religião. Segundo Junqueira (2010, p.67) Santa Catarina foi o primeiro estado a autorizar, em 1996, o curso de licenciatura em Ciências da Religião. O professor que se dedica a uma licenciatura específica de formação de professores de ensino religioso evita "o proselitismo e a doutrinação e garante a democracia e o reconhecimento da diversidade cultural" (JUNQUEIRA, 2010, p.69). Nesse processo de formação de professores de Ensino Religioso, urge resguardar o pluralismo de ideias e de concepções pedagógicas, valorizando-se a importância do respeito à diversidade de tradições religiosas, evitando o proselitismo e a doutrinação.

Chaves (2017, p.202) aponta a situação brasileira que, desde 1934 as instituições religiosas ficaram responsáveis pela formação de professores de Ensino Religioso. Essa perspectiva tendia a formar professores doutrinadores e proselitistas. O cenário é modificado com a LDB 9394/96 e o parecer no.4, de 11 de março de 1997, que propôs a formação específica para as diversas áreas de conhecimento. Pela experiência que tivemos e pelo próprio relato dos formandos do curso de Ciências da Religião da Universidade Estadual do Norte do Paraná, percebemos e defendemos a importância de que sejam criados cursos específicos para a formação de professores de Ensino Religioso numa perspectiva de Ciência da Religião. 
Também é importante que o departamento de recursos humanos dos respectivos estados da Federação também priorize a atribuição de aula de ensino religioso para quem cursou licenciatura em Ciências da Religião.

Amaral, Oliveira, Souza (2017) analisam o projeto pedagógico do curso de Licenciatura em Ciências das Religiões da Universidade Federal da Paraíba e apontam no sentido da importância de se considerar a laicidade do Estado e uma perspectiva do ensino religioso como área do conhecimento. Os autores indicaram, em sua análise das produções científicas sobre ensino religioso, uma variedade de produções que defendem sua existência no currículo sem a preocupação de se observar a laicidade do Estado.

Vale lembrar que as produções sobre formação docente de ensino religioso focalizam mais a formação continuada do que a formação inicial específica em ciências da religião. Neste sentido, os autores nos lembram que o Acordo de 13 de novembro de 2008 da Santa Sé foi um retrocesso na perspectiva de um ensino laico porque o documento assinado acabou por valorizar mais a Igreja Católica em detrimento de outras instituições e abriu espaço para um retorno de um Ensino Religioso confessional.

Amaral, Oliveira e Souza (2017, p.277) também apontam que há uma falta de orientações específicas para a formação de professores de Ensino Religioso. Como fica sob responsabilidade dos estados e municípios essas orientações, acaba por ter uma grande variedade de orientações.

Caetano (2007, p.156) aponta que, historicamente, a condição do professor de Ensino Religioso torna-se precária porque não existe concurso específico para a área e há momentos na história em que um professor de Religião sequer percebia um salário para lecionar. A autora destaca a importância de que existam cursos de licenciatura para a formação específica de professores de Ensino Religioso e que esses cursos contemplem aspectos históricos, filosóficos, sociológicos, psicológicos, antropológicos, educacionais das religiões, a fim de possibilitar que o futuro professor disponha de condições de se situar nos debates contemporâneos mais amplos sobre as Ciências da Religião.

Caetano (2007, p.171) ainda aponta para a necessidade de não se confundir Ciências da Religião com Teologia. O campo da Teologia é o campo da confessionalidade, por sua vez, as Ciências da Religião não priorizam uma religião e seu objeto de estudo são as diversas manifestações do sagrado. A autora destaca, em suas considerações, diversas iniciativas do FONAPER em possibilitar uma formação mínima para professores de Ensino Religioso como, 
por exemplo, em 2000, a criação de curso à distância de 120 horas denominado "Ensino Religioso, Capacitação para um Novo Milênio".

Caetano (2007, p. 328) conclui sua dissertação apontando para a necessidade de um Ensino Religioso que supere os pressupostos apenas confessionais e assuma um âmbito de discussões “filosóficas, antropológicas e pluralistas", respeitando a diversidade.

Neste sentido a BNCC (2017, p, 435) estabelece que:

A Constituição Federal de 1988 (artigo 210) e a LDB n 9.394/1996 artigo 33, alterado pela Lei $n^{\circ} 9.475 / 1997$ ) estabeleceram os princípios e os fundamentos que devem alicerçar epistemologias e pedagogias do Ensino Religioso, cuja função educacional, enquanto parte integrante da formação básica do cidadão, é assegurar o respeito à diversidade cultural religiosa, sem proselitismos. Mais tarde, a Resolução CNE/CEB nº 04/2010 e a Resolução CNE/CEB nº 07/2010 reconheceram o Ensino Religioso como uma das cinco áreas de conhecimento do Ensino Fundamental de 09 (nove) anos.

Da mesma forma, a Secretaria Estadual de Educação do Paraná aponta em suas diretrizes curriculares para o Ensino Religioso (SEED-PR, ano 2018, p. 400) que os professores devam:

1. Conhecer os aspectos estruturantes das diferentes tradições/organizações religiosos e filosofias de vida, a partir de pressupostos científicos, filosóficos, estéticos e éticos.

2. Compreender, valorizar e respeitar as manifestações religiosas e filosofias de vida, suas experiências e saberes, em diferentes tempos, espaços e territórios.

3. Reconhecer e cuidar de si, do outro, da coletividade e da natureza, enquanto expressão de valor da vida.

4. Conviver com a diversidade de crenças, pensamentos, convicções, modos de ser e viver.

5. Analisar as relações entre as tradições religiosas e os campos da cultura, da política, da economia, da saúde, da ciência, da tecnologia e do meio ambiente.

6. Debater, problematizar e posicionar-se frente aos discursos e práticas de intolerância, discriminação e violência de cunho religioso, de modo a assegurar os direitos humanos no constante exercício da cidadania e da cultura de paz.

É importante frisar que o curso de Ciências da Religião e Ensino Religioso oferecido pela UENP, embora tivesse trazido em sua ementas e programas elementos que vão de encontro com o conteúdo das diretrizes curriculares nacionais para a Ciência da Religião e com a Base 
Nacional Comum Curricular para o Ensino Religioso, não pode se nortear pois tais normativas pois foi iniciado em 2016, o curso com duração de dois anos teve a seguinte fundamentação legal:

\section{Legislação Básica}

- Lei n. 9394/96 : Lei de Diretrizes e Bases da Educação Nacional

- Decreto Federal no 3.726/99 : Formação em nível superior de professores para atuar na educação básica e dá outras providências.

- Decreto Lei no 3.860/01 : Organização do Ensino Superior, avaliação de cursos e instituições.

\section{Legislação para o Ensino Religioso}

- Constituição Federal: Art. 210, § $1^{\circ}$

- Lei n. 9394/1996 Lei de Diretrizes e Bases da Educação Nacional - LDB Art. 33

- Lei 9.475/97 - Dá nova redação ao Art. 33 da LDB;

- Resolução CEB-CNE n. 002/1998 - Diretrizes para o Ensino Fundamental - Art. $3^{\circ}$

Princípios e áreas de conhecimento (dentre elas a de Educação Religiosa).

- Resolução CEB-CNE n. 007/2010 - fixa as áreas de conhecimento do currículo da base comum nacional para o ensino fundamental de nove anos, dentre elas a de Ensino Religioso (Art. $\left.15, \S 6^{\circ}\right)$.

- Deliberação CEE-PR n. 001/2006 - normatiza a disciplina no estado do Paraná.

Com base nos fundamentos legais apontados e levando-se em conta o perfil do corpo docente disponível, chegou-se a seguinte matriz curricular :

\begin{tabular}{|l|c|c|c|}
\hline \multicolumn{2}{|c|}{ MODULO } & \multicolumn{3}{c|}{ Carga Horária } \\
\hline & Teórica & Prática & Total \\
\hline Geografia da Religião II & 35 & 10 & 45 \\
\hline História das Religiões II & 35 & 10 & 45 \\
\hline Didática e Metodologia do Ensino Religioso I & 35 & 10 & 45 \\
\hline Psicologia e experiência religiosa & 35 & 10 & 45 \\
\hline Religiões Afro-brasileiras e indígenas no Brasil & 35 & 10 & 45 \\
\hline \multicolumn{2}{|c|}{ Carga Horária } & & 225 \\
\hline
\end{tabular}

\section{MODULO}

\section{Carga Horária}

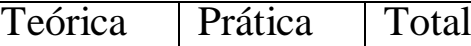




\begin{tabular}{|l|c|c|c|}
\hline Geografia e culturas religiosas no Brasil & 35 & 10 & 45 \\
\hline História das Religiões III & 35 & 10 & 45 \\
\hline Didática e Metodologia do Ensino Religioso I & 35 & 10 & 45 \\
\hline Sociologia e Religiões & 35 & 10 & 45 \\
\hline Língua Brasileira de Sinais - Libras I & 35 & 10 & 45 \\
\hline \multicolumn{2}{|c|}{ Carga Horária Total } & 225 \\
\hline
\end{tabular}

\begin{tabular}{|l|c|c|c|}
\hline \multicolumn{2}{|c|}{ MODULO } & \multicolumn{3}{c|}{ Carga Horária } \\
\hline & Teórica & Prática & Total \\
\hline Geografia e culturas religiosas no Paraná & 35 & 10 & 45 \\
\hline Pentecostalismo no Brasil & 35 & 10 & 45 \\
\hline Catolicismo no Brasil & 35 & 10 & 45 \\
\hline Filosofia e Religiões & 35 & 10 & 45 \\
\hline Língua Brasileira de Sinais - Libras II & 35 & 10 & 45 \\
\hline & \multicolumn{2}{|c|}{ Carga Horária Total } & 225 \\
\hline
\end{tabular}

Este quadro de disciplinas objetivou formar o profissional com o seguinte perfil :

a) O licenciado em Ciências da Religião apto a aplicar e descrever métodos de ensino e aprendizagem voltados para a compreensão dos fenômenos religiosos em suas múltiplas manifestações através de diferentes olhares.

b) O Cientista da Religião preparado para promover uma abordagem do fenômeno religioso que promova a transdisciplinariedade levando a compreensão da religião e religiosidades como algo presente no legado cultural da humanidade, mantendo sintonia com as políticas educacionais em nível estadual e federal.

c) O egresso capaz, além das atividades próprias à docência, de produzir pesquisas que contribuam para novos estudos das religiões e religiosidades, bem como, de métodos que permeiem essas dimensões de forma que o cientista das religiões compreenda e torne compreensível seu objeto de pesquisa.

\section{Análise de dados}

Como um dos instrumentos de pesquisa, foi aplicado questionário para os formados na modalidade PARFOR da primeira turma de Ciências da Religião da UENP - Universidade Estadual do Norte do Paraná. Contaram com 5 respondentes. Abaixo o questionário que foi aplicado aos participantes: 


\section{Idade:}

18 a 30 anos

30 a 40 anos

mais de 40 anos

\section{Leciona ensino religioso a quanto tempo:}

menos de 05 anos

entre 5 a 10 anos

mais de 10 anos

\section{Primeira Licenciatura}

\section{Ciências Humanas}

\section{Ciências Exatas}

\section{Outro}

1- $\quad$ O que motivou a cursar a licenciatura em ciências da religião?

2- $\quad$ Quais são as 5 primeiras palavras que lhe vem à mente quando você pensa na palavra religião. Numere em ordem de importância.

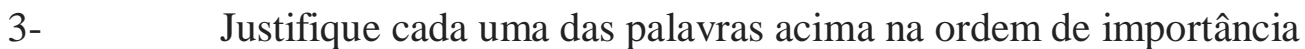

4- Para você o que é religião?

5- $\quad$ Como foi sua experiência e aprendizagem ao cursar o curso licenciatura

\section{Ciências da Religião?}

6- $\quad$ Para você qual a contribuição do Ensino Religioso no currículo da educação básica?

7- $\quad$ Há sempre uma tentativa de se implantar um Ensino Religioso confessional. Como você percebe esta proposta?

8- $\quad$ Na sua visão de cientista da religião como você percebe a importância das religiões no contexto da sociedade em que vivemos?

9- $\quad$ Você modificou seu pensamento sobre Ensino Religioso depois de cursar uma licenciatura em Ciências da Religião? Se sim, em que modificou? 


\section{relegens thrésketa}

10- $\quad$ Você acredita que seja importante que a disciplina Ensino Religioso fosse ensinada por profissionais formados em Ciências da Religião? Justifique sua resposta. 11- Para você quais as características de um bom professor de Ensino Religioso? 12- $\quad$ Na sua opinião como ser organizado o Ensino Religioso no Brasil?

Por uma questão dos limites desta pesquisa, propomo-nos a discutir as questões sublinhadas e em trabalhos posteriores apresentar os resultados das demais questões.

\section{Caracterização dos sujeitos de Pesquisa}

Os sujeitos de pesquisa são 5 egressos do Curso de Ciências da Religião da Universidade Estadual do Norte do Paraná. Abaixo apresentamos três informações sobre os 5 respondentes.

- Quanto à idade: $75 \%$ de 30 a 40 anos; $25 \%$ mais de 40 anos

- Leciona Ensino Religioso: 75\% entre 05 e 10 anos; 25\% mais de 10 anos

- Primeira Licenciatura: 100\% Ciências Humanas

\section{Respostas}

Apresentamos as respostas das questões sublinhadas e posteriormente realizamos uma discussão sobre os resultados da pesquisa.

\section{1) O que motivou a cursar a licenciatura em Ciências da Religião?}

P1: Gosto do assunto e queria aprender mais sobre para poder trabalhar a desconstrução do pensamento intolerante religioso.

P2: Formação para atuar nas aulas de Ensino Religioso

P3: Pode estar habilitado para ensinar.

P4: Pode apreender mais, para ensinar com mais propriedade sobre o assunto religião.

P5: O desejo de aprender mais sobre religiões; já era professora de Ensino Religioso e quis aperfeiçoar meu conhecimento na área

2)Como foi sua experiência e aprendizagem ao cursar o curso licenciatura Ciências da Religião? P1: Aprendi a abrir minha mente a respeito do assunto. Me proporcionou um olhar diferente a respeito da diversidade religiosa. 
P2: Estudar o fenômeno religioso foi uma experiência que auxílio no meu amadurecimento enquanto profissional, passei a compreender, a partir de um olhar científico as diferentes manifestações do sagrado.

P3: Foi muito importante na minha formação. Depois do curso de Ciências da Religião tenho uma outra visão sobre o fenômeno religioso.

P4: Minha experiência foi muito positiva. Gostei muito de ter cursado Ciências da Religião. Houve uma diversidade de disciplinas que possibilitou que eu pudesse rever meus posicionamentos sobre o ensino religioso.

P5: Foi muito proveitoso. Os professores contribuiram muito na minha mudança de mentalidade sobre as religiões. Confesso que tinha um pouco de preconceito com algumas religiões

\section{3)Para você qual a contribuição do ensino religioso no currículo da educação básica?}

P1: Ao agregar mais conhecimento, torna - se mais fácil repassar o conteúdo aos meus alunos. A compreensão do diferente traz a possibilidade do respeito à diversidade religioso que existe no Brasil e no mundo.

P2: É de fundamental importância para a formação para a cidadania das futuras gerações.

P3: De fundamental importância na formação para o cotidiano.

P4: É de fundamental importância. A religião faz parte da vida social dos nossos alunos e eles aprenderem mais sobre as diversas religiões ajuda para vivermos em sua sociedade mais tolerante

P5: Não respondeu esta questão

4)Há sempre uma tentativa de se implantar um ensino religioso confessional. Como você percebe esta proposta?

P1: Não deixando esquecerem que o Estado é laico. E a sala de aula deve ser um espaço para todos.

P2: Essa tentativa e extremamente tendenciosa, pois tira dos estudantes a possibilidade de conhecer o q está além do cristianismo, e consequentemente a possibilidade de ser um sujeito crítico.

P3: Lamentável isso. Acredito que devemos respeitar as diversidades.

P4: Devemos repudiar toda espécie de busca do ensino confessional do ensino religioso, devemos buscar o respeito pela diversidade. 
P5: É lamentável que as instituições religiosas tenham influência sobre os sistemas de ensino a ponto de fazer pressão para que o ensino religioso seja confessional. O Ensino Religioso deveria ter o nome modificado para Ciências da Religião porque a própria nomenclatura é problemática.

5) Você modificou seu pensamento sobre ensino religioso depois de cursar uma licenciatura em

\section{Ciências da Religião? Se sim, em que modificou?}

P1: Sim, uma mente mais receptiva a diversidade e um olhar mais crítico com pensamentos estereotipados, preconceituoso.

P2: Sim. O estudo transforma e com essa licenciatura tive a oportunidade de compreender, cientificamente, o fenômeno religioso em diferentes contexto. O ponto primordial é quanto a focar o estudo na diversidade religiosa a partir do respeito as diferenças, deixando o julgamento em último plano e se possível não julgar.

P3: Sim, modifiquei sim. Principalmente na respeito para diversas tradições religiosas diferentes da minha religião.

P4: Sim, antes pensava mais no sentido cristão de ser religioso, hoje percebo de modo mais aberto para as diversas tradições religiosas diferentes da cristã.

P5: Sim, tinha preconceito com algumas religiões e hoje percebo os valores existentes nas mais diversas religiões.

6) Você acredita que seja importante que a disciplina ensino religioso fosse ensinada por profissionais formados em Ciências da Religião? Justifique sua resposta.

P1: Com certeza. Afinal de que outra maneira a diversidade e conhecimento chegará as pessoas se não por meio da educação.

P2: Sim. Pois tem se uma formação profissional adequada, que não está presa ao ensino confessional. Tornando possível a produção de conhecimento crítico. E não simplesmente o estudo de datas comemorativas.

P3: Com certeza. Se a disciplina fosse ensinada por profissionais formados na disciplina teríamos outro contexto.

P4:Como toda disciplina quando o profissional é formado naquela disciplina faz toda a diferença 
P5:Sim, como a matemática deve ser ensinada por alguém formado em matemática, ensino religioso deve ser ensinado por alguém formado na área

\section{Análise das respostas}

Da questão número 1, podemos perceber que a motivação para cursar Ciências da Religião na UENP foi para os participantes por conta da busca de procurar conhecer mais sobre as religiões e melhorar o próprio ensino da disciplina. Destaque-se a fala do participante 1 que enfatizou a contribuição do curso na desconstrução do pensamento religioso intolerante. Destaque-se também o fato de grande parte dos formados já terem sido professores de ensino religioso antes do ingresso no curso

Da questão número 2, podemos destacar que segundo as falas dos participantes puderam abrir suas mentes para uma nova compreensão epistemológica sobre o Ensino Religioso após ter cursado a licenciatura em Ciências da Religião. O curso propiciou para o participante 1 "um olhar diferente a respeito da diversidade religiosa. Foi destacado também o amadurecimento profissional enquanto professor de ensino religioso. O curso propiciou aos formados a oportunidade de reverem seus próprios conceitos e eliminarem o preconceito com algumas religiões.

Com relação à pergunta 3 sobre a contribuição do Ensino Religioso no currículo da educação básica, foi destacado nas respostas a questão da importância na formação do cidadão o conhecimento sobre as religiões que marcam a vida das pessoas.

Com relação à pergunta 4 , que pedia informações sobre a tentativa de se implantar um Ensino Religioso confessional, as respostas marcaram um repúdio em relação a tal entendimento. Na visão dos formados, o ensino confessional de Ensino Religioso já é algo superado e não podemos regredir e aceitar a doutrinação no momento em que seria oportuno um crescimento pessoal e aprofundamento teórico sobre a diversidade das religiões.

Na questão 5, ainda perguntando aos egressos sobre as contribuições no seu pensamento e do curso de Ciências da Religião em sua existência, destacou-se que o curso pode contribuir a compreender cientificamente o fenômeno religio so em diferentes contextos. Constatou-se que o curso contribuiu para que os estudantes ampliassem seu conhecimento sobre as religiões e assim percebessem a diversidade de posicionamento religioso, superando toda espécie de preconceito. $\mathrm{O}$ respeito às diversas tradições religiosas foi uma das contribuições elencadas nas falas dos participantes. 
Quanto à questão 6, que versa sobre a importância de um profissional formado em Ciências da Religião para ensinar Ensino Religioso, percebemos que os formados entendem que é de suma importância que cada vez mais interessados frequentem cursos de licenciatura em ciências da religião para possibilitar que um número maior de professores habilitados em Ciências da Religião ocupem a sala de aula, superando assim um ensinamento doutrinário nas escolas. A licenciatura em Ciências da Religião possibilita um distanciar-se do proselitismo.

\section{Conclusão}

A presente investigação evidenciou a importância de cursos de licenciatura específica de Ciências da Religião para formar professores habilitados para o Ensino Religioso. Pela revisão de literatura, ficou evidenciado o quanto ainda, por vezes, o Ensino Religioso é tratado de forma desvalorizada pelos sistemas de ensino e acabam lecionando a disciplina pessoas com reta intenção, mas despreparadas cientificamente para ensinar uma visão de diversidade diante das tradições religiosas.

Urge ressaltar a experiência positiva da Universidade Estadual do Norte do Paraná ao formar sua primeira turma de Ciências da Religião. Pelas respostas dos participantes do questionário, percebe-se o quanto modificaram sua visão sobre as religiões após aprofundarem seus estudos sobre as Ciências da Religião.

Na UENP a partir das experiências nas pesquisas desenvolvidas pelos Historiadores e Cientistas da Religião, pensou-se no Ensino Religioso, enquanto parte integrante da formação básica do cidadão e área do conhecimento da base nacional comum (Resolução CNE/CEB n ${ }^{\circ}$ 4, de 13 de julho de 2010), responsável por assegurar o respeito a diversidade cultural religiosa na escola.

Nesta perspectiva, o curso de formação de professores Ensino Religioso objetivou proporcionar o conhecimento dos elementos básicos que compõem o fenômeno religioso, a fim de possibilitar esclarecimentos sobre o direito à diferença, valorizando o pluralismo e a diversidade cultural presente na sociedade, para que as culturas sejam conhecidas em mesmo grau e valor, promovendo e exercitando a liberdade de concepções e a construção da autonomia e da cidadania, prerrogativas de um estado laico e democrático.

As diferentes crenças, grupos e tradições religiosas, bem como a ausência delas, foram vistos como aspectos da realidade que devem ser socializados e abordados como dados 
antropológicos e socioculturais, capazes de contribuir na interpretação e na fundamentação das ações humanas.

Notou-se ainda, a necessidade de um estudo do fenômeno religioso em um estado laico, a partir de pressupostos científicos, visa à formação de cidadãos críticos e responsáveis, capazes de discernir a dinâmica dos fenômenos religiosos, que perpassam a vida em âmbito pessoal, local e mundial.

É na perspectiva da formação plena do cidadão, no contexto de uma sociedade cultural e religiosamente diversa, na qual todas as crenças, expressões religiosas e não-religiosas devem ser respeitadas, que se inseriu o curso de Ciências da Religião e Ensino Religioso da UENP, propondo perspectivas curriculares para que o Ensino Religioso possa garantir o acesso aos conhecimentos religiosos da humanidade, incentivando o diálogo e relações positivas entre culturas e religiosidades distintas.

As diferentes crenças, grupos e tradições religiosas, bem como a ausência delas, foram aspectos abordados como dados antropológicos e socioculturais, capazes de contribuir na interpretação e na fundamentação das ações humanas.

Os resultados evidenciaram um impacto não apenas epistemológico na concepção do ensino religioso após a formação em Ciências da Religião, como também uma mudança de visão didática sobre o que constitui a identidade de ser professor de Ensino Religioso.

\section{REFERÊNCIAS}

AMARAL, Daniela Patti do; OLIVEIRA, Renato José de; SOUZA, Evelin Christine Fonseca de; Argumentos para a formação do professor de ensino religioso no projeto pedagógico do curso de Ciências das Religiões da UFPB: que docente se pretende formar? Revista Brasileira de Estudos Pedagógicos, v.98, n.249, p.270-292, maio/ago 2017

BRASIL. Ministério da Educação. Conselho Nacional de Educação . Conselho Pleno. RESOLUÇÃO No 5, de 2018, Disponível em http://portal.mec.gov.br/index.php?option=com_docman\&view=download\&alias $=105531$ rcp005-18\&category_slug=janeiro-2019-pdf\&Itemid=30192

BRASIL. Ministério da Educação. Conselho Nacional de Educação . Câmara de Educação Básica . RESOLUÇÃO No 4, de 2010, Disponível em http://portal.mec.gov.br/index.php?option=com_docman\&task=doc_download\&gid=5916\&It emid $=$

BRASIL. Base Nacional Comum Curricular: Educação Infantil e Ensino Fundamental. Brasília: MEC/Secretaria de Educação Básica, 2017. Disponível em http://basenacionalcomum.mec.gov.br/ 
CAETANO, Maria Cristina. O ensino religioso e a formação de seus professores: dificuldades e perspectivas. Dissertação. Programa de Pós Graduação em Educação PUC MG. Belo Horizonte, 2007

CHAVES, Pedro Jônatas da Silva. A identidade docente do professor de Ensino Religioso nos documentos oficiais dos entes federados. Revista Educare, v.1, n.2, p.201-202, jul.dez. 2017

DEMO, Pedro. Metodologia da Pesquisa em Ciências Sociais.3.ed. São Paulo : Atlas, 1995.

DISSENHA, Isabel Cristina Piccinelli, JUNQUEIRA, Sérgio Rogério Azevedo. Fundamentos do Ensino Religioso. Curitiba: Editora IESDE, 2015.

DOMINGOS, Marília de Franceschi Neto. Ensino Religioso e Estado Laico: uma lição de tolerância . REVER - Revista de Estudos da Religião. São Paulo, n.3, p.45-70, Setembro, 2009. Disponível em https://www.pucsp.br/rever/rv3_2009/index.html

GERHARDT, T.E. ; SILVEIRA, D.T. ( Orgs.) . Métodos de Pesquisa. Porto Alegre : Editora da UFRGS, 2009.

GRESCHAT, Hans-Jürgen. O que é ciência da religião ? São Paulo: Paulinas, 2005.

JUNQUEIRA, Sérgio Rogério Azevedo. Formação do Professor de Ensino Religioso: um processo em construção no contexto brasileiro. Revista de Estudos da Religião, junho.2010.

JUNQUEIRA, S.R.A.; KLUCK,C.R.; GABRIEL JÚNIOR, R.F.;RODRIGUES, E.M.F. Socialização do saber e produção científica no Ensino Religioso. Porto Alegre: Editora Fi, 2017.

PARANÁ. Referencial Curricular do Paraná: princípios, direitos e orientações. Curitiba : Conselho Estadual de Educação, 2018. Disponível em http://www.educadores.diaadia.pr.gov.br/arquivos/File/bncc/2018/referencial_curricular_parana_c ee.pdf

UNIVERSIDADE ESTADUAL DO NORTE DO PARANÁ. Pró-Reitoria de Graduação. Projeto Pedagógico do Curso de Ciências da Religião e Ensino Religioso. Jacarezinho, 2015.

USARSKI, Frank (org.) O espectro disciplinar da Ciência da Religião. São Paulo: Paulinas, 2007. 